\title{
In Vitro Evaluation of Five Antimicrobial Peptides against the Plant Pathogen Erwinia amylovora
}

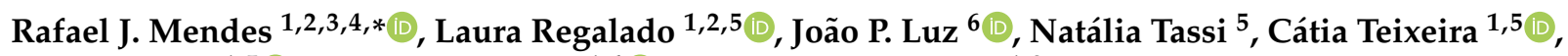 \\ Paula Gomes ${ }^{1,5} \mathbb{D}$, Fernando Tavares ${ }^{1,4}\left(\mathbb{D}\right.$ and Conceição Santos ${ }^{1,2}$ \\ 1 Faculty of Sciences, University of Porto, 4169-007 Porto, Portugal; up201604469@edu.fc.up.pt (L.R.); \\ catia.teixeira@fc.up.pt (C.T.); pgomes@fc.up.pt (P.G.); ftavares@fc.up.pt (F.T.); csantos@fc.up.pt (C.S.) \\ 2 LAQV-REQUIMTE, Biology Department, Faculty of Sciences, University of Porto, 4169-007 Porto, Portugal \\ 3 CITAB - Centre for the Research and Technology of Agro-Environmental and Biological Sciences, \\ University of Trás-os-Montes e Alto Douro, 5000-801 Vila Real, Portugal \\ 4 CIBIO-Research Centre in Biodiversity and Genetic Resources, InBIO, Associated Laboratory, \\ Faculty of Sciences, University of Porto, 4485-661 Vairão, Portugal \\ 5 LAQV-REQUIMTE, Department of Chemistry and Biochemistry, Faculty of Sciences, University of Porto, \\ 4169-007 Porto, Portugal; natalia.tcpf@fc.up.pt \\ 6 QRural, Polytechnic Institute of Castelo Branco, School of Agriculture, 6000-084 Castelo Branco, Portugal; \\ j.p.luz@ipcb.pt \\ * Correspondence: rafael.mendes@fc.up.pt
}

check for updates

Citation: Mendes, R.J.; Regalado, L.; Luz, J.P.; Tassi, N.; Teixeira, C.; Gomes, P.; Tavares, F.; Santos, C. In Vitro Evaluation of Five Antimicrobial Peptides against the Plant Pathogen Erwinia amylovora. Biomolecules 2021, 11, 554. https://doi.org/10.3390/ biom11040554

Academic Editor:

Vladimir N. Uversky

Received: 22 March 2021

Accepted: 8 April 2021

Published: 9 April 2021

Publisher's Note: MDPI stays neutral with regard to jurisdictional claims in published maps and institutional affiliations.

Copyright: (c) 2021 by the authors. Licensee MDPI, Basel, Switzerland. This article is an open access article distributed under the terms and conditions of the Creative Commons Attribution (CC BY) license (https:// creativecommons.org/licenses/by/ $4.0 /)$.

\begin{abstract}
Fire blight is a major pome fruit trees disease that is caused by the quarantine phytopathogenic Erwinia amylovora, leading to major losses, namely, in pear and apple productions. Nevertheless, no effective sustainable control treatments and measures have yet been disclosed. In that regard, antimicrobial peptides (AMPs) have been proposed as an alternative biomolecule against pathogens but some of those AMPs have yet to be tested against E. amylovora. In this study, the potential of five AMPs (RW-BP100, CA-M, 3.1, D4E1, and Dhvar-5) together with BP100, were assessed to control E. amylovora. Antibiograms, minimal inhibitory, and bactericidal concentrations (minimal inhibitory concentration (MIC) and minimal bactericidal concentration (MBC), growth and $\mathrm{IC}_{50}$ were determined and membrane permeabilization capacity was evaluated by flow cytometry analysis and colony-forming units (CFUs) plate counting. For the tested AMPs, the higher inhibitory and bactericidal capacity was observed for RW-BP100 and CA-M (5 and 5-8 $\mu \mathrm{M}$, respectively for both MIC and MBC), whilst for $\mathrm{IC}_{50}$ RW-BP100 presented higher efficiency (2.8 to $\left.3.5 \mu \mathrm{M}\right)$. Growth curves for the first concentrations bellow MIC showed that these AMPs delayed E. amylovora growth. Flow cytometry disclosed faster membrane permeabilization for CA-M. These results highlight the potential of RW-BP100 and CA-M AMPs as sustainable control measures against E. amylovora.
\end{abstract}

Keywords: antimicrobial activity; CA-M; Dhvar-5; D4E1; fire blight; flow cytometry; membrane permeabilization; RW-BP100; 3.1

\section{Introduction}

Fire blight is a destructive disease that affects primarily some chain-of-value pome fruit trees of the Rosaceae family, namely, pear (Pyrus communis L.), apple (Malus domestica Borkh.), loquats (Eriobotrya japonica (Thunb.) Lindl.), quince (Cydonia oblonga Mill.), and other ornamental species [1,2]. This disease leads to production losses, being a major concern for pome fruit producers around the world, with great economic impact where its present [3]. The etiological agent responsible for this disease is the quarantine bacterium Erwinia amylovora (Burril) Winslow et al., a Gram-negative of the Erwiniaceae family, which has been considered as one of the top ten plant pathogenic bacteria $[4,5]$. This pathogen was first reported in North America, but is currently spread to Europe (United Kingdom, Spain, France, Italy, Hungary, and Portugal), South Korea, New Zealand, and the Middle East [6-14]. 
One of the main problems of fire blight is the lack of effective control measures to stop its high destructive effects in plants and its dissemination $[15,16]$. Current methods rely mostly on preventive measures, with cultural control practices, like, avoidance of production areas favorable for disease development, proper fertilization, and irrigation, shortening of the blooming period, and pruning or decimation of infected trees [16,17]. Regarding the chemical controls available, the use of copper-based compounds has led to emerging phytotoxicity associated with high doses of copper in the soil, and acquisition of resistance by bacteria $[18,19]$. Antibiotics, like streptomycin and oxytetracycline, although reasonably effective, present serious limitations, namely, the lack of efficacy at lower doses, high production cost and phytotoxicity, which associated with the emerging antibiotic resistance, has led many regions (e.g., European Union) to ban their use, although they are still allowed in regions like North America and others [20,21]. These limitations in controlling fire blight urge for new, safe, and efficient control strategies. In response to this, one of the most studied fields in the last years is the identification of bacteriophages and antagonistic bacteria [22-24], and the application of essential oils [25,26]. Moreover, antimicrobial peptides (AMPs) present highly promising outcomes [27-31].

AMPs can be found in diverse organisms, such as insects, mammals including humans, reptiles, amphibians, and plants, being components of their immune/defense system $[20,32,33]$. Most AMPs are short chained cationic and amphipathic amino acids (aa), adopting $\alpha$-helix, $\beta$-sheet, or loop conformations [32-35]. They possess a broad spectrum of action against numerous microorganisms, including fungi and bacteria, due to their capacity to interact with microbial cell membranes, which confers them an antimicrobial activity mainly, but often not exclusively, due to membrane permeation or disruption (e.g., formation of pores or micelles, respectively) [32-34,36]. AMPs can also interact with intracellular targets, including ribosomes, or nucleic acids after traversing the cell membrane, which leads to inhibition of DNA transcription, mRNA synthesis, protein synthesis, and lead to formation of reactive oxygen species (ROS) [32,33]. One of the advantages of the AMPs is that generally they do not possess specific enzyme targets like antibiotics do, which propels AMPs less likely to draw resistance from microbial mutations [31,33].

Several AMPs have been reported active against several Gram-negative plant pathogenic bacteria, such as E. amylovora, Pseudomonas syringae, Xanthomonas vesicatoria [37], Erwinia carotovora subsp. carotovora, Erwinia carotovora subsp. atroseptica [38,39], Xylella fastidiosa [40], Xanthomonas oryzae, Xanthomonas campestris [41], and Pseudomonas syringae pv. actinideae [42], all with an outer-membrane containing lipopolysaccharide (LPS) that serves as permeability membrane against chemical compounds [43]. One such AMPs is the linear undecapeptide BP100 (KKLFKKILKYL-NH2), with bioactivity against E. amylovora. BP100 has high antimicrobial activity, inducing low hemolysis and phytotoxicity [29,44-46]. Nevertheless, BP100 has limited activity against Gram-negative bacteria, and to surpass that limitation an analogue was developed, namely, RW-BP100 (RRLFRRILRWL-NH2), which demonstrated improved efficacy against Gram-negative bacteria such as Escherichia coli, Klebsiella pneumoniae, and Pseudomonas aeruginosa, whilst demonstrating efficacy in some Gram-positive bacteria [47]. Other AMP reported as effective against Gram-negative bacteria include the cecropin A-melittin (CAM) hybrid (KWKLFKKIGAVLKVL-NH2) [48,49] and peptide 3.1 (KKLLKWLLKLL-NH2), an LK peptide studied in the last years, with promising results against e.g., Shigella dysenteriae, K. pneumoniae, and E. coli [50,51]. Another AMP with demonstrated efficacy against Gramnegative Pseudomonas syringae pv. tabaci and Xanthomonas campestris pv. malvacearum bacteria is D4E1 (FKLRAKIKVRLRAKIKL-NH2) [52]. Relevantly, none of these promising AMPs, RW-BP100, CA-M, 3.1, or D4E1, have ever been tested against E. amylovora, which compelled us to fill this gap. Indeed, identification of valuable AMPs to fight plant pathogens and tackle crop-relevant infectious diseases is still underway.

Hence, the effect of BP100, RW-BP100, CA-M, 3.1, and D4E1 was evaluated in this work, at different doses and on a collection of E. amylovora, to assess the range of bioactivity of these AMPs in this bacterium. For comparison, we have also included the AMP Dhvar-5 (LLLFLLKKRKKRKY-NH2), widely reported to possess potent action against Gram-positive 
bacteria like Staphylococcus aureus [53] and which was not tested against E. amylovora before either. Dose effects were compared by performing concentration tests and assessing the integrity of cell membrane and cell viability, to disclose the most effective AMPs.

\section{Materials and Methods}

\subsection{Peptide Synthesis}

BP100, RW-BP100, CA-M, D4E1, 3.1 and Dhavar-5 peptides (Table 1) were assembled following an orthogonal Fmoc/tBu scheme [54], on a Rink-amide-MBHA-derivatized matrix of copoly (styrene $/ 1 \%$ divinylbenzene), $100-200$ mesh, $0.36 \mathrm{mmol} \cdot \mathrm{g}^{-1}$ functionalization (NovaBiochem, Merck KGaA, Darmstadt, Germany). Peptide synthesis was performed on an automated Symphony X synthesizer from Gyros Protein Technologies (Tucson, AZ, USA), at the Laboratory of Peptide and Peptide-Nucleic Acid Synthesis of the Faculty of Sciences of the University of Porto (POP-UP). All peptides presented a purity degree $(>98 \%)$ that was quantitated by analytical reverse-phase high performance liquid chromatography (RP-HPLC) using a Hitachi-Merck LaChrom Elite system equipped with a quaternary pump, a thermostated automated sampler, and a diode-array detector (DAD). Analyses were performed with a reverse-phase C18 column $(150 \times 4.6 \mathrm{~mm}$ ID and $5 \mu \mathrm{m}$ pore size, Merck) at a $1 \mathrm{~mL} / \mathrm{min}$ flow rate using a $1-100 \%$ of solvent $B(A C N)$ in solvent $A$, for $30 \mathrm{~min}$, with detection at $220 \mathrm{~nm}$. An LCQ-DecaXP LC-MS system from ThermoFinnigan, equipped with both a DAD detector and an electrospray ionization-ion trap mass spectrometer (ESI/IT MS) was used to confirm peptide identity. RP-HPLC chromatograms and ESI-IT MS spectra of synthesized peptides are provided as Supplementary Information (Figures S1-S12).

Table 1. Sequence and properties of peptides used in this work.

\begin{tabular}{|c|c|c|c|}
\hline Peptide & Sequence & Net Charge $^{1}$ & $\mathrm{MW}(\mathrm{Da})^{2}$ \\
\hline BP100 & KKLFKKILKYL-NH 2 & +6 & 1419.9 \\
\hline RW-BP100 & RRLFRRILRWL-NH & +6 & 1583.0 \\
\hline CA-M & KWKLFKKIGAVLKVL-NH ${ }_{2}$ & +6 & 1769.2 \\
\hline D4E1 & FKLRAKIKVRLRAKIKL-NH $_{2}$ & +9 & 2079.4 \\
\hline 3.1 & KKLLKWLLKLL-NH $_{2}$ & +5 & 1393.9 \\
\hline Dhvar-5 & LLLFLLKKRKKRKY-NH ${ }_{2}$ & +8 & 1845.3 \\
\hline
\end{tabular}

${ }^{1}$ Estimated net charge at $\mathrm{pH} 7 ;^{2} \mathrm{MW}$ : molecular weight. Source: Pepdraw.com accessed on 01 March 2021.

\subsection{Bacterial Strains}

Thirty-six E. amylovora strains, collected in pear and apple orchards from the North and Centre of Portugal between 2010 and 2017, were evaluated (Table 2). Type strain LMG 2024 was used as a reference. Bacterial strains were preserved at $-80{ }^{\circ} \mathrm{C}$ in $30 \%$ glycerol and $70 \%$ King's B (KB) medium. Otherwise stated, strains were cultured in $\mathrm{KB}$ medium at $28^{\circ} \mathrm{C}$.

Table 2. Portuguese Erwinia amylovora strains used in this work.

\begin{tabular}{|c|c|c|c|c|c|}
\hline \multirow{2}{*}{ Strain } & \multicolumn{2}{|c|}{ Host } & \multirow{2}{*}{ Isolated From } & \multirow{2}{*}{ Geographic Origin } & \multirow{2}{*}{ Year } \\
\hline & Species & Cultivar & & & \\
\hline Ea 230 & Pear & 'Rocha' & Exudate & Alcobaça & 2010 \\
\hline Ea 240 & Pear & 'Rocha' & Exudate & Alcobaça & 2010 \\
\hline Ea 250 & Pear & 'Rocha' & Branch & Alcobaça & 2010 \\
\hline Ea 260 & Pear & 'Rocha' & Branch & Alcobaça & 2010 \\
\hline Ea 270 & Pear & 'Passe Crassane' & Branch & Alcobaça & 2010 \\
\hline Ea 280 & Pear & 'Rocha' & Exudate & Alcobaça & 2011 \\
\hline Ea 310 & Pear & 'Rocha' & Exudate & Alcobaça & 2011 \\
\hline Ea 320 & Pear & 'Rocha' & Branch & Alcobaça & 2011 \\
\hline
\end{tabular}


Table 2. Cont.

\begin{tabular}{|c|c|c|c|c|c|}
\hline \multirow{2}{*}{ Strain } & \multicolumn{2}{|c|}{ Host } & \multirow{2}{*}{ Isolated From } & \multirow{2}{*}{ Geographic Origin } & \multirow{2}{*}{ Year } \\
\hline & Species & Cultivar & & & \\
\hline Еa 340 & Pear & 'Rocha' & Branch & Alcobaça & 2011 \\
\hline Ea 350 & Pear & 'Rocha' & Branch & Alcobaça & 2011 \\
\hline Ea 390 & Apple & 'Royal Gala' & Necrotic fruit & Alcobaça & 2011 \\
\hline Ea 410 & Apple & 'Royal Gala' & Semi-necrotic fruit & Alcobaça & 2011 \\
\hline Еa 430 & Apple & 'Royal Gala' & Semi-necrotic fruit & Alcobaça & 2011 \\
\hline Ea 450 & Pear & 'Rocha' & Exudate & Alenquer & 2015 \\
\hline Ea 460 & Pear & 'Rocha' & Exudate & Alenquer & 2015 \\
\hline Ea 470 & Pear & 'Rocha' & Exudate & Alenquer & 2015 \\
\hline Еa 480 & Pear & 'Rocha' & Exudate & Alenquer & 2015 \\
\hline Ea 490 & Pear & 'Rocha' & Branch & Alenquer & 2015 \\
\hline Ea 500 & Pear & 'Rocha' & Branch & Alenquer & 2015 \\
\hline Ea 510 & Pear & 'Rocha' & Exudate & Alenquer & 2015 \\
\hline Ea 520 & Pear & 'Rocha' & Exudate & Alenquer & 2015 \\
\hline Ea 540 & Pear & 'Carapinheira' & Branch & Caldas da Rainha & 2015 \\
\hline Ea 570 & Pear & 'Carapinheira' & Branch & Caldas da Rainha & 2015 \\
\hline Ea 580 & Pear & 'Carapinheira' & Branch & Caldas da Rainha & 2015 \\
\hline Еa 610 & Apple & 'Gala' & Branch & Cadaval & 2015 \\
\hline Ea 620 & Apple & 'Gala' & Branch & Cadaval & 2015 \\
\hline Ea 630 & Apple & 'Gala' & Branch & Cadaval & 2015 \\
\hline Еa 670 & Pear & 'Rocha' & Branch & Cadaval & 2015 \\
\hline Еa 680 & Pear & 'Rocha' & Branch & Cadaval & 2015 \\
\hline Ea 720 & Pear & 'Rocha' & Branch & Cadaval & 2015 \\
\hline Ea 730 & Pear & Unidentified & Branch & West * & 2017 \\
\hline Ea 740 & Pear & Unidentified & Branch & West * & 2017 \\
\hline Ea 750 & Pear & Unidentified & Branch & West * & 2017 \\
\hline Ea 780 & Pear & Unidentified & Branch & West * & 2017 \\
\hline Ea 790 & Pear & Unidentified & Branch & West* & 2017 \\
\hline Ea 820 & Pear & Unidentified & Branch & West * & 2017 \\
\hline
\end{tabular}

* These isolates have been isolated in the West region of Portugal, which includes the municipalities of Alcobaça, Caldas da Rainha, Alenquer and Cadaval.

\subsection{Antibiogram Assay}

The antibiogram assay was applied to screen the effects of the six AMPs against E. amylovora. The 37 bacterial strains were grown overnight in Mueller Hinton (MH) Broth (Liofilchem, Téramo, Italy) at $25^{\circ} \mathrm{C}$ and $180 \mathrm{rpm}$. A bacterial suspension was adjusted to 0.1 at an optical density at $600 \mathrm{~nm}\left(\mathrm{OD}_{600}\right)$, which corresponds to approximately between $1 \times 10^{8}$ to $1 \times 10^{9} \mathrm{CFU} \cdot \mathrm{mL}^{-1}$, and $1 \mathrm{~mL}$ of the bacterial suspension was grown on $\mathrm{MH}$ agar medium (Liofilchem, Téramo, Italy). Subsequently, $1 \mu \mathrm{L}$ of eight concentrations $(0.4,1.6,6.2$, $25,50,100,150$, and $200 \mu \mathrm{M}$ ) of each AMP were applied directly in the Petri dish. After $24 \mathrm{~h}$ of incubation at $25^{\circ} \mathrm{C}$, results were recorded using the Gel Doc XR+ (Bio-Rad Laboratories, Hercules, CA, USA) to evaluate the inhibition halo. Results were considered positive (+) when halo formation occurred, and negative $(-)$ when there was no observable halo. Each experiment was repeated three times. 


\subsection{Antimicrobial Activity of AMPs}

To assess the antimicrobial activity of the AMPs, four parameters were evaluated, namely, the minimal inhibitory concentration (MIC), the minimal bactericidal concentration (MBC), the half-maximal inhibitory concentration $\left(\mathrm{IC}_{50}\right)$, and the growth during $24 \mathrm{~h}$. After analyzing the results of the antibiogram assay, only the three most effective AMPs against E. amylovora were further tested, namely, BP100, RW-BP100, and CA-M, and their concentrations were adjusted to $1.6,3.4,5,8,12,20,30,70$, and $100 \mu \mathrm{M}$. E. amylovora strains used were the most representative of the collection, namely, Ea 230, Ea 320, Ea 390, Ea 490, Ea 630, Ea 680, and Ea 820, and the type strain LMG 2024 (Table 1), which corresponded to strains that were collected from different years, different hosts from several orchards and with different virulence levels (data not shown). For the MIC assay, the bacterial strains were grown overnight in $2 \times \mathrm{MH}$ broth at $25{ }^{\circ} \mathrm{C}$ and $180 \mathrm{rpm}$ and then adjusted to an $\mathrm{OD}_{600}$ of 0.1 . The bacterial suspension $(75 \mu \mathrm{L})$ was applied in a 96-well titration plate, to which the nine concentrations of each AMP were previously added ( $75 \mu \mathrm{L}$ each), in order to obtain a final concentration of 1:1. During a period of $24 \mathrm{~h}$, the titration plate was incubated at $25^{\circ} \mathrm{C}$ in constant shaking, with hourly absorbance reading at $600 \mathrm{~nm}$, in the Multiskan ${ }^{\mathrm{TM}}$ GO (Thermo Fisher Scientific, Waltham, MA, USA). Results were obtained after $24 \mathrm{~h}$ when inhibition of growth was visibly detected. The positive control was chlortetracycline $(50 \mu \mathrm{M})$ and the negative control was $\mathrm{H}_{2} \mathrm{O}$. Immediately afterwards, $10 \mu \mathrm{L}$ from the bacterial suspensions of each well were grown on $\mathrm{KB}$ at $25^{\circ} \mathrm{C}$ during $24 \mathrm{~h}$. MBC concentration was obtained when there was no visible colony growth. Since equal values of MIC and MBC could be obtained for the same AMP in different strains, $\mathrm{IC}_{50}$ values were determined through non-linear fitting, resorting to GraphPad Prism 8 software (GraphPad Software, San Diego, CA, USA), and growth curves were assessed for the concentrations below the MIC value of each strain for each AMP. Each experiment was repeated three times.

\subsection{Evaluation of AMPs Membrane Permeabilization through Flow Cytometry}

For in vitro assessment of the AMPs in cell viability, flow cytometry (FC) was used. E. amylovora type strain LMG 2024 was grown overnight in $\mathrm{KB}$ broth at $25^{\circ} \mathrm{C}$ and $180 \mathrm{rpm}$, later the bacterial culture was centrifuged for $5 \mathrm{~min}$ at $2500 \mathrm{rpm}$. Pellet was resuspended in PBS (10 mM, pH 7.2), and $\mathrm{OD}_{600}$ was adjusted to 0.1. The concentrations tested for BP100, RWBP100, and CA-M were 5 and $8 \mu \mathrm{M}$, which correspond to the MIC values obtained previously. An aliquot of $50 \mu \mathrm{L}$ of bacteria with the respective AMP was stained with propidium iodide (PI) in a final concentration of $1 \mathrm{mg} \cdot \mathrm{mL}^{-1}$. Fluorescence intensities were recorded at $\mathrm{t}_{0}, \mathrm{t}_{10}, \mathrm{t}_{30}$, $t_{60}$, and $t_{120} \mathrm{~min}$. Flow cytometry was performed on a BD Accuri ${ }^{\mathrm{TM}}$ C6 Plus (BD Bioscience, Franklin Lakes, NJ, USA). Data were collected for a total of 20,000 events and analyzed by gating using flow cytometry software C6 Plus Analysis (BD Bioscience, Franklin Lakes, NJ, USA). Viability was inversely proportional to PI fluorescence level. Isopropyl alcohol $23 \%$ was used as a positive control. Each experiment was repeated three times.

\subsection{Assessment of Colony Forming Units (CFUs)}

The colony-forming units (CFU) method was applied to assess the number of viable cells after treatment with BP100, RW-BP100, and CA-M in the FC assay. Briefly, after 120 min of exposure of the E. amylovora type strain LMG 2024 to each AMP at different concentrations ( 5 and $8 \mu \mathrm{M}$ ), a tenfold dilution series was applied. After that, $10 \mu \mathrm{L}$ of each bacterial dilution were applied directly on KB medium in triplicate, followed by incubation at $28{ }^{\circ} \mathrm{C}$ for $24 \mathrm{~h}$. Photographs were obtained for each treatment for each AMP, and the number of colonies obtained was counted to assess CFU. Each experiment was repeated three times.

\subsection{Statistical Analysis}

Comparisons between the treatments for $\mathrm{IC}_{50}$, and $\mathrm{CFU}$ were analyzed through Oneway Anova, whilst FC was analyzed through Two-way Anova using GraphPad Prism 8 for 
Windows (GraphPad Software, San Diego, CA, USA). Results were considered statistically different when $p<0.05$.

\section{Results}

To assess the efficacy of six AMPs (BP100, RW-BP100, CA-M, 3.1, D4E1, and Dhvar-5) against $E$. amylovora, a diverse collection of strains of this pathogen was tested for several endpoints, regarding their susceptibility and viability.

\subsection{Peptide Synthesis}

All peptides listed in Table 1 were synthesized by standard solid-phase peptide synthesis (SPPS) protocols based on the Fmoc/tBu orthogonal protection scheme [54]. The peptides were purified with high purity ( $\geq 98 \%)$, according to reverse-phase high performance liquid chromatography (RP-HPLC) analysis, and their expected molecular weights (MW) were confirmed by electrospray ionization-ion trap mass spectrometry (ESI-IT MS) (Figures S1-S12).

\subsection{Antibiogram Assay}

The antibiogram assay for the six AMPs disclosed different levels of susceptibility to each peptide, with some AMPs revealing higher efficacy than others (Figure 1, Supplementary Table S1). BP100 was the most effective AMP, with 30 strains susceptible at $25 \mu \mathrm{M}(83.3 \%)$, and only 6 strains susceptible at $50 \mu \mathrm{M}(16.7 \%)$, with the type strain LMG 2024 presenting this same result. Regarding RW-BP100 and CA-M, both AMPs showed similar efficiency, with 20 and 24 strains being susceptible at $25 \mu \mathrm{M}$ (55.6 and 66.7\%), 15 and 8 strains susceptible at $50 \mu \mathrm{M}(41.6$ and $22.2 \%)$, and 1 and 4 strains susceptible at $100 \mu \mathrm{M}(2.8$ and $11.1 \%)$, respectively. Type strain LMG 2024 was susceptible at $100 \mu \mathrm{M}$ for both RW-BP100 and CA-M. The strains tested, after exposure to 3.1 and D4E1 AMPs, presented lower susceptibility results, with 3.1 displaying 9 strains susceptible at $50 \mu \mathrm{M}(25 \%), 25$ strains susceptible at $100 \mu \mathrm{M}(69.4 \%)$, 1 strain susceptible at $150 \mu \mathrm{M}(2.8 \%)$, and 1 strain susceptible at $200 \mu \mathrm{M}(2.8 \%)$, while type strain LMG 2024 presented susceptibility at $100 \mu \mathrm{M}$. Regarding the exposure to D4E1, 3 strains were susceptible at $25 \mu \mathrm{M}(8.3 \%), 4$ strains were susceptible at $50 \mu \mathrm{M}(11.1 \%), 19$ strains were susceptible at $100 \mu \mathrm{M}(52.8 \%), 7$ strains were susceptible at $150 \mu \mathrm{M}(19.4 \%), 2$ strains were susceptible at $200 \mu \mathrm{M}(5.6 \%)$, and 1 strain did not present any susceptibility (2.8\%). Type strain LMG 2024 exposed to D4E1 displayed susceptibility at $100 \mu \mathrm{M}$. For Dhvar-5 the strains tested showed no susceptibility.

\subsection{Antimicrobial Activity of AMPs}

After the first screening of the six AMPs activity against the 36 strains of E. amylovora, the three most efficient AMPs were chosen to be further analyzed against eight representative strains of that pathogen (Table 3).

The MIC values ranged between 5 and $8 \mu \mathrm{M}$ for both BP100 and CA-M, whilst $5 \mu \mathrm{M}$ was obtained for RW-BP100 against all strains. The MBC values ranged between 8 and $20 \mu \mathrm{M}$ for BP100 and between 5 and $8 \mu \mathrm{M}$ for CA-M, while for RW-BP100 they were equal to the MIC values $(5 \mu \mathrm{M})$. The MIC and MBC values displayed the same results for some strains, and $\mathrm{IC}_{50}$ allowed to further differentiate those results (Figure 2).

Although no statistically significant difference was observed between the strains in each AMP, different susceptibility for each AMP was detected among them regarding the tested strains $(p<0.05)$, namely, between BP100 and CA-M, and RW-BP100 and CA-M, with BP100 and RW-BP100 presenting generally lower $\mathrm{IC}_{50}$ values than CA-M. In addition to $\mathrm{IC}_{50}$, growth curves were analyzed for every strain for each AMP regarding the concentrations below their respective MIC (Supplementary Figures S13-S15). For BP100, every strain exposed to $1.6 \mu \mathrm{M}$ displayed similar growth to those that were not exposed to the peptide, while the strains exposed to the concentration of $3.4 \mu \mathrm{M}$ (LMG 2024 and Ea 320 strains), and $5 \mu \mathrm{M}$ (remaining strains), had a considerably delayed lag phase, starting around 14-16 h after those strains either exposed to $1.6 \mu \mathrm{M}$ or not exposed (Supplementary Figure S13). Regarding the strains 
exposed to RW-BP100 at 1.6 $\mu \mathrm{M}$, growth was similar to those not exposed to the peptide; in turn, when exposed to $3.4 \mu \mathrm{M}$, the lag phase was delayed, but contrary to BP100, the majority started their growth around 6-8 h after the strains that were either exposed to $1.6 \mu \mathrm{M}$ or not exposed (Supplementary Figure S14). Strains exposed to 1.6 and 3.4 $\mu \mathrm{M}$ of CA-M presented similar behavior to that of those exposed to RW-BP100, but when exposed to a concentration of $5 \mu \mathrm{M}$ they presented the same behavior than the ones exposed to the same concentration of BP100 (Supplementary Figure S15).

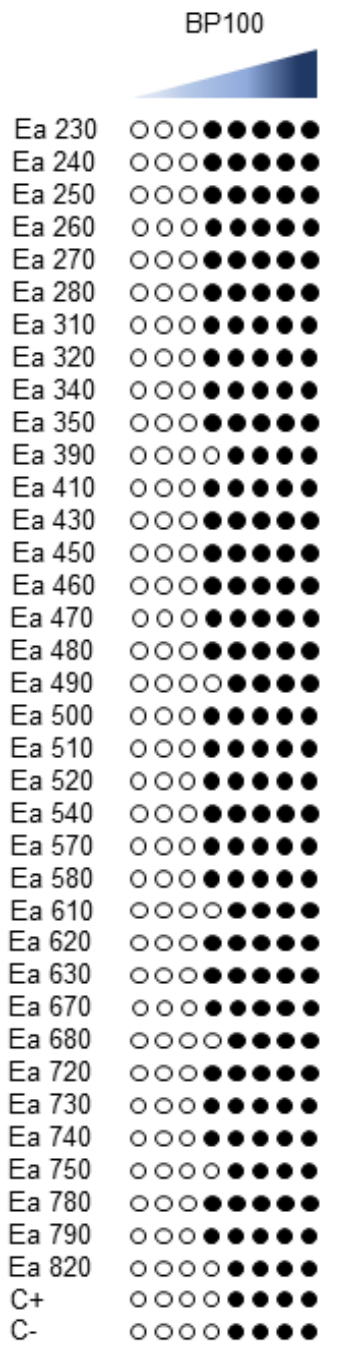

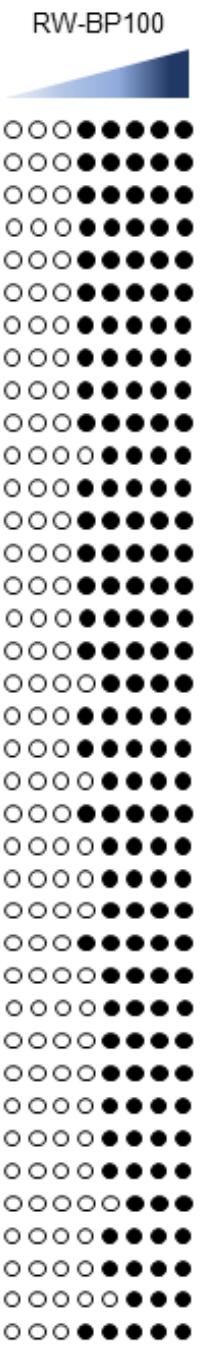

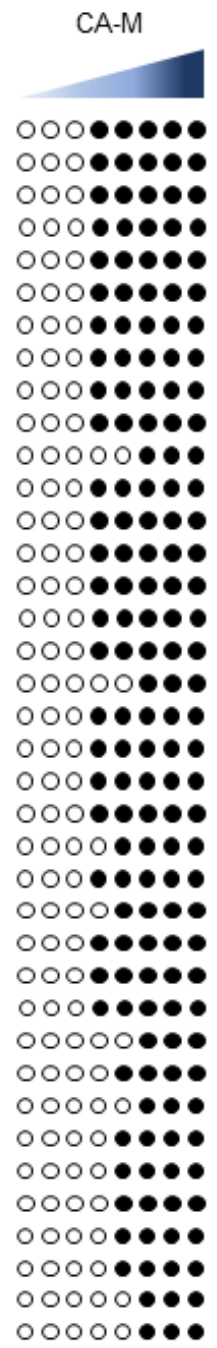

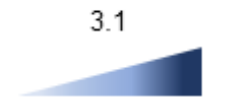

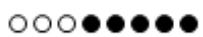

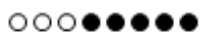

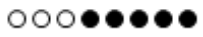
0 00 부우웅 ○००부우웅

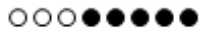

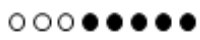

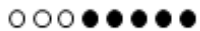
0000 ○०००부웅 0000000

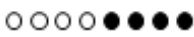
○০০부붑

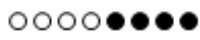

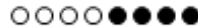
O 000 ○०००부웅 0000

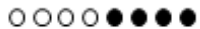

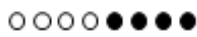

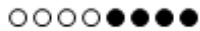
0000 0 000

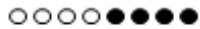
○○০०•부붕

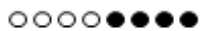
○ 000

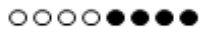

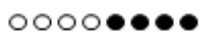

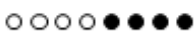

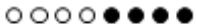

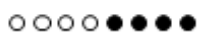

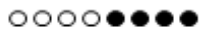
00000 ○००•••• $00000 \bullet$ ०००००••• ○०००•부웅

\begin{tabular}{cc} 
D4E1 & Dhvar 5 \\
\hline $0000 \bullet \bullet \bullet$ & 00000000 \\
$0000 \bullet \bullet$ & 00000000 \\
$00000 \bullet \bullet$ & 00000000 \\
$0000 \bullet \bullet \bullet$ & 00000000 \\
$0000 \bullet \bullet \bullet$ & 00000000 \\
$000 \bullet \bullet \bullet$ & 00000000 \\
$000 \bullet \bullet \bullet \bullet$ & 00000000 \\
$000 \bullet \bullet \bullet \bullet$ & 00000000 \\
$000000 \bullet \bullet$ & 00000000 \\
$0000000 \bullet$ & 00000000 \\
$0000000 \bullet$ & 00000000 \\
$000000 \bullet \bullet$ & 00000000 \\
$00000 \bullet \bullet$ & 00000000 \\
$000000 \bullet \bullet$ & 00000000 \\
$00000 \bullet \bullet$ & 00000000 \\
$00000 \bullet \bullet \bullet$ & 00000000 \\
$00000 \bullet \bullet$ & 00000000 \\
$00000 \bullet \bullet$ & 00000000 \\
$00000 \bullet \bullet$ & 00000000 \\
$00000 \bullet \bullet$ & 00000000 \\
$000000 \bullet$ & 00000000 \\
$000000 \bullet \bullet$ & 00000000 \\
$00000 \bullet \bullet$ & 00000000 \\
$000000 \bullet \bullet$ & 00000000 \\
$00000 \bullet \bullet$ & 00000000 \\
$00000 \bullet \bullet \bullet$ & 00000000 \\
$00000 \bullet \bullet \bullet$ & 00000000 \\
$00000 \bullet \bullet$ & 00000000 \\
$00000 \bullet \bullet \bullet$ & 00000000 \\
$00000 \bullet \bullet \bullet$ & 00000000 \\
$00000 \bullet \bullet$ & 00000000 \\
$00000 \bullet \bullet$ & 00000000 \\
$00000 \bullet \bullet \bullet$ & 00000000 \\
00000000 & 00000000 \\
$000000 \bullet \bullet$ & 00000000 \\
$00000 \bullet \bullet \bullet$ & 00000000 \\
$00000 \bullet \bullet \bullet$ & 00000000 \\
$00000 \bullet \bullet \bullet$ & $000000 \bullet \bullet$
\end{tabular}

Figure 1. Antibiogram susceptibility to antimicrobial peptides (AMPs) BP100, RW-BP100, CA-M, 3.1, D4E1, and Dhvar-5. Each AMP was tested using eight concentrations, namely, 0.4, 1.6, 6.2, 25, 50, 100, 150, and $200 \mu \mathrm{M}$ (increasing concentrations are represented at blue, left to right). $\bigcirc$ : Normal growth; •: Inhibited growth. C+: Type strain LMG 2024.

\subsection{Evaluation of AMPs Membrane Permeabilization through Flow Cytometry}

To disclose the peptide-induced bacterial membrane disruption, flow cytometry was applied resorting to a dye that intercalates with nucleic acids when membrane permeabilization occurs, in order to quantify the loss of membrane integrity caused by the AMPs. The results obtained regarding cell viability were inversely proportional to the fluorescence level obtained for each concentration during a period of time (Figure 3). 
Table 3. AMPs values of minimal inhibitory concentration (MIC), minimal bactericidal concentration $(\mathrm{MBC})$ and obtained for the eight Erwinia amylovora strains $(n=3)$.

\begin{tabular}{|c|c|c|c|}
\hline AMP & Strain & $\operatorname{MIC}(\mu \mathrm{M})$ & MBC $(\mu \mathrm{M})$ \\
\hline \multirow{8}{*}{ BP100 } & LMG 2024 & 5 & 8 \\
\hline & Ea 230 & 8 & 8 \\
\hline & Ea 320 & 5 & 8 \\
\hline & Еa 390 & 8 & 20 \\
\hline & Ea 490 & 8 & 12 \\
\hline & Ea 630 & 8 & 8 \\
\hline & Ea 680 & 8 & 8 \\
\hline & Ea 820 & 8 & 8 \\
\hline \multirow{8}{*}{ RW-BP100 } & LMG 2024 & 5 & 5 \\
\hline & Ea 230 & 5 & 5 \\
\hline & Ea 320 & 5 & 5 \\
\hline & Ea 390 & 5 & 5 \\
\hline & Ea 490 & 5 & 5 \\
\hline & Еa 630 & 5 & 5 \\
\hline & Ea 680 & 5 & 5 \\
\hline & Еa 820 & 5 & 5 \\
\hline \multirow{8}{*}{ CA-M } & LMG 2024 & 8 & 8 \\
\hline & Ea 230 & 8 & 8 \\
\hline & Ea 320 & 8 & 8 \\
\hline & Ea 390 & 5 & 5 \\
\hline & Еa 490 & 8 & 8 \\
\hline & Ea 630 & 8 & 8 \\
\hline & Ea 680 & 5 & 5 \\
\hline & Ea 820 & 8 & 8 \\
\hline
\end{tabular}

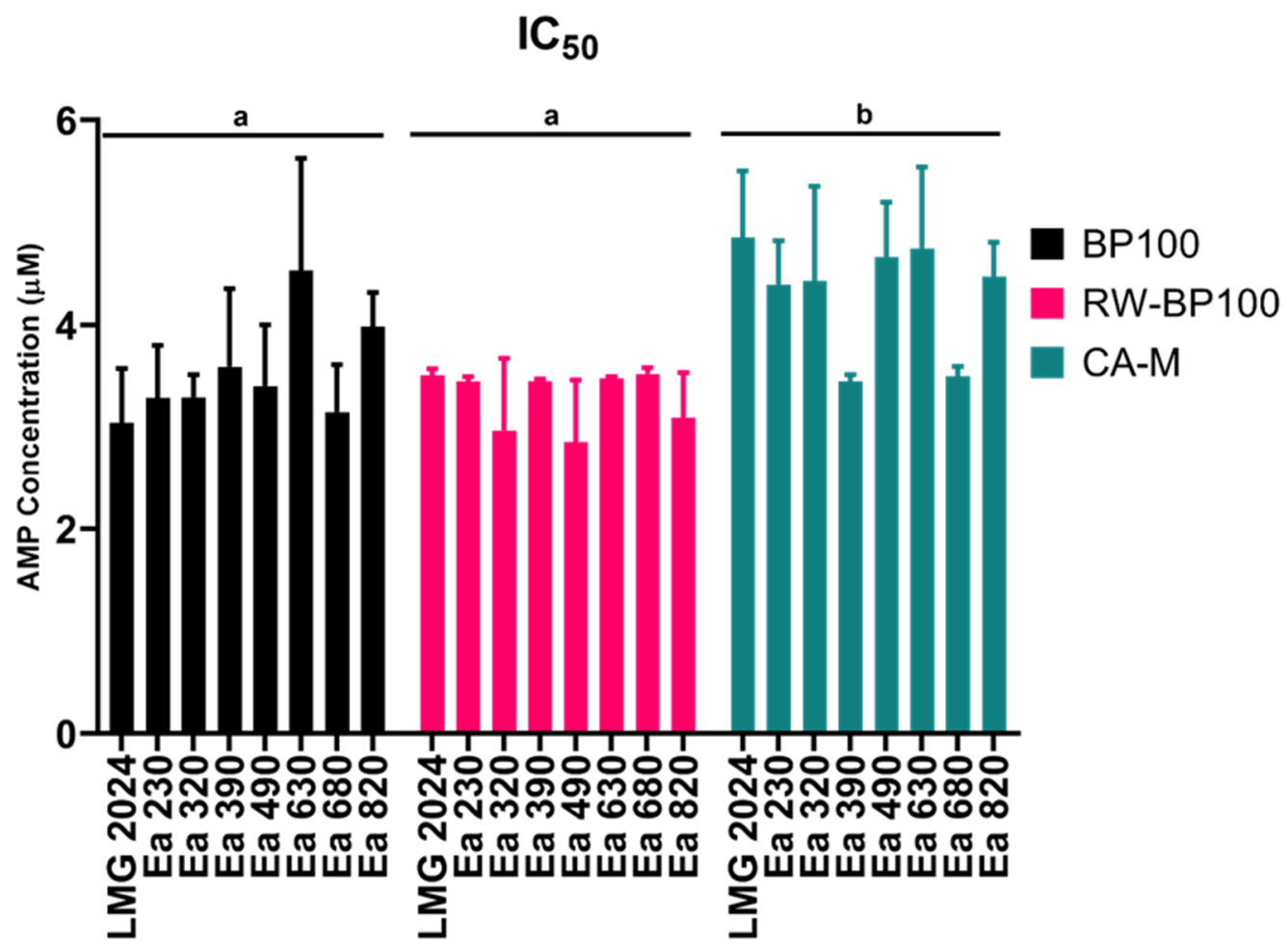

Figure 2. Half maximal inhibitory concentration $\left(\mathrm{IC}_{50}\right)$ of eight Erwinia amylovora strains against three AMPs: BP100, RW-BP100, and CA-M. Vertical bars: mean value with standard deviation $(n=3)$. Different letters means significant differences for each AMP assay $(p<0.0001)$. 
A

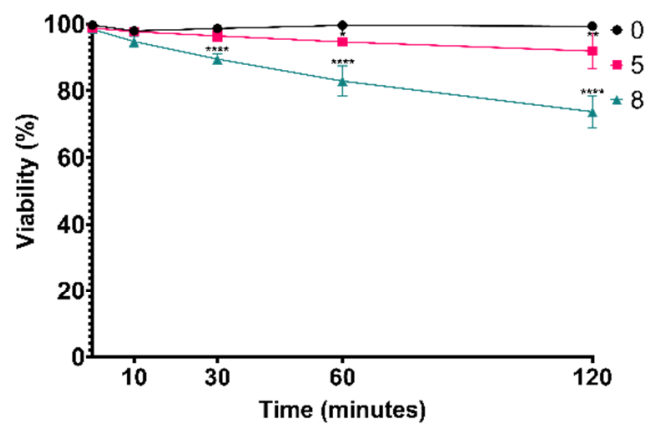

C

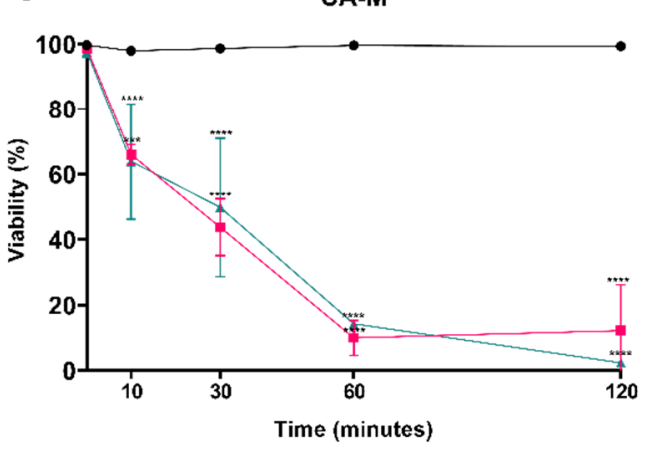

B

RW-BP100

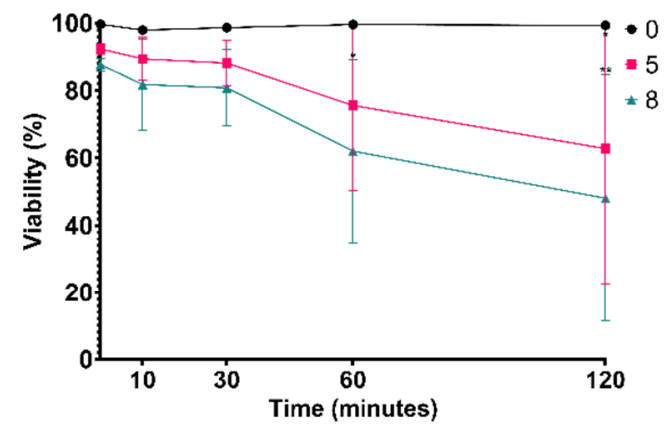

D

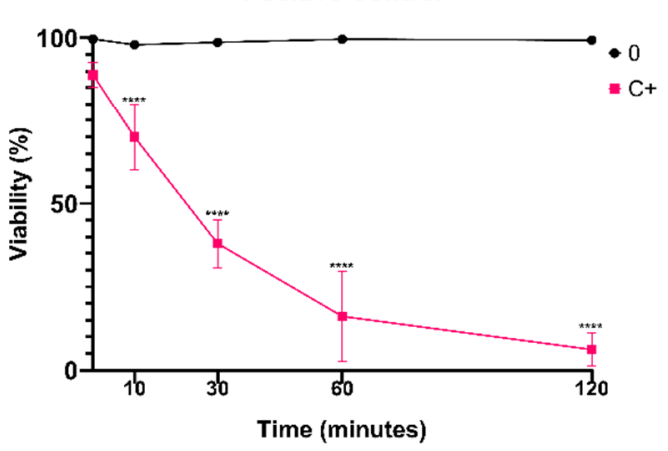

Figure 3. Viability of Erwinia amylovora strain LMG 2024 after exposure to increasing concentrations of AMPs during 120 min. (A) BP100; (B) RW-BP100; (C) CA-M; and (D) Isopropyl alcohol 23\%. Viability was inversely proportional to propidium iodide (PI) fluorescence level in each time point. Vertical bars: mean value with standard deviation $(n=3) ; *$, ${ }^{* *}, * *$, and ${ }^{* * *}$ refer to the statistical significances for differences in each time point of the analysis with $p<0.05, p<0.01$, $p<0.001$, and $p<0.0001$, respectively.

BP100 started to show statistically significant values $(p<0.0001)$ in the decrease of cell viability at 30-min exposure at the concentration of $8 \mu \mathrm{M}(89.5 \%)$. After 60 and $120 \mathrm{~min}$, the same decrease of cell viability was observed ( 82.9 and $73.7 \%$, respectively) $(p<0.0001)$, while for the exposure at $5 \mu \mathrm{M}$ the decrease of cell viability was statistically significant after 60 and 120 min ( 94.6 and 91.9\%, respectively) ( $p<0.05$ and 0.001, respectively) (Figure 3A). Regarding RW-BP100, cell viability decreased $(p<0.05)$ at 5 and $8 \mu \mathrm{M}$ after 120 -min exposure $(62.8$ and $48.1 \%$ respectively), and after 60 -min exposure at $8 \mu \mathrm{M}(62 \%)$ (Figure $3 \mathrm{~B})$. CA-M was the most efficient AMP, with a significant $(p<0.0001)$ reduction in cell viability throughout all time points for every concentration tested, except at time of exposure $\left(\mathrm{t}_{0}\right)$ (Figure $3 \mathrm{C}$ ), with expressive decrease at 60 and $120 \mathrm{~min}$ (below 15\%). Positive control displayed a statistically significant reduction $(p<0.0001)$ of cell viability similar to CA-M (Figure 3D).

\subsection{Assessment of Colony Forming Units (CFUs)}

In order to further disclose and confirm the FC results, CFU plate counting was employed for every condition after a 120-min exposure to AMPs (Figure 4). For BP100, the 5 and $8 \mu \mathrm{M}$ concentrations displayed a statistically significant decrease $(p<0.05)$ of CFU in comparison with the control $\left(5.5 \times 10^{9} \mathrm{CFU} \cdot \mathrm{mL}^{-1}\right.$ and $4 \times 10^{7} \mathrm{CFU} \cdot \mathrm{mL}^{-1}$, respectively). RW-BP100 led to a statistically significant reduction $(p<0.05)$ in CFU in the control condition after 120 min since the start of the assay and no recovery of the bacterium was observed for every concentration tested $(p<0.05)$. For CA-M, no recovery after $24 \mathrm{~h}$ of incubation in the plates was observed for every concentration tested $(p<0.05)$. Furthermore, at the concentrations of 5 and $8 \mu \mathrm{M}, \mathrm{BP} 100$ presented statistically significant difference $(p<0.0001)$ when compared with RW-BP100 and CA-M, due to recovering cells (Figure 4). 


\section{LMG 2024}

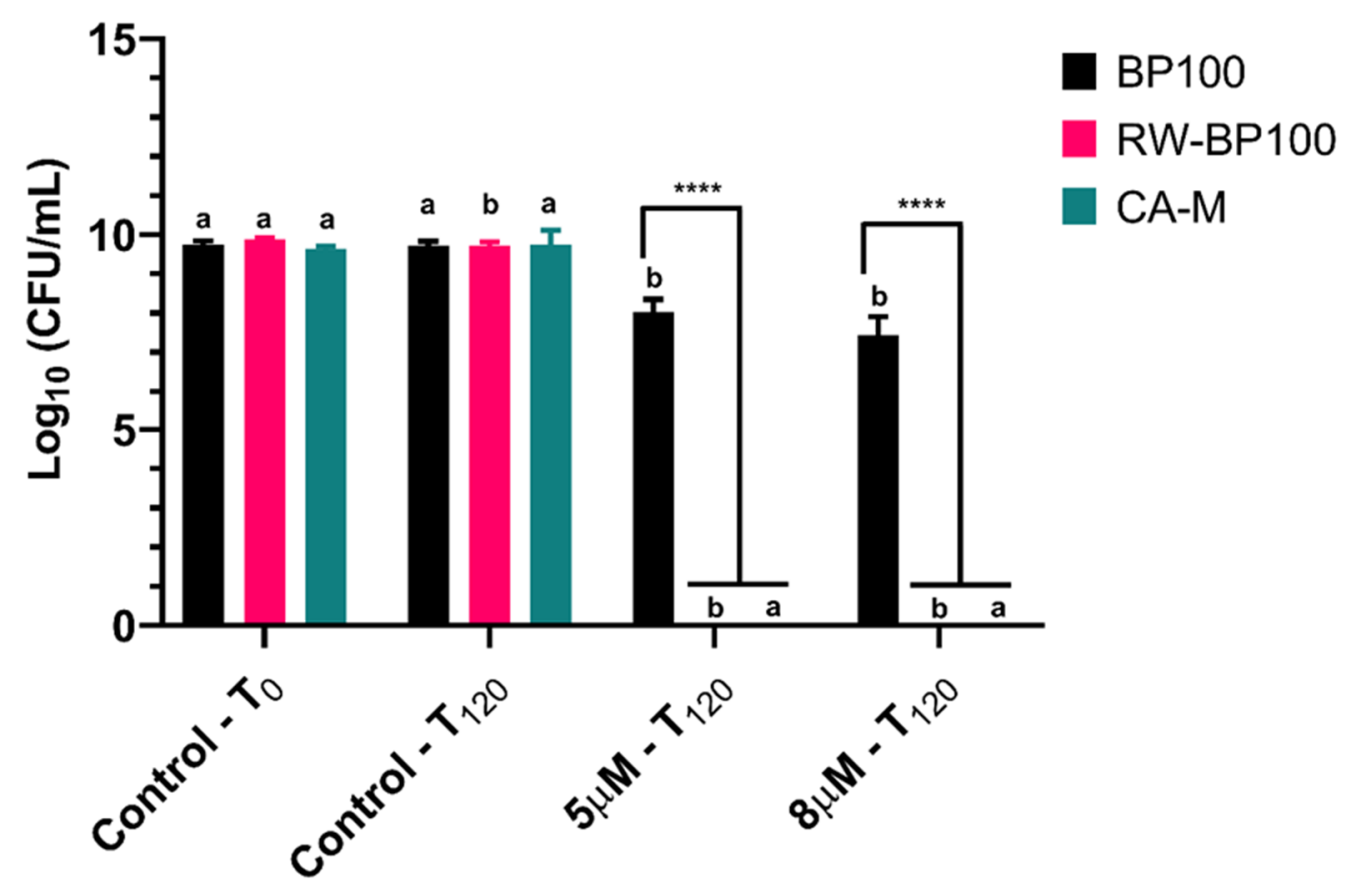

Figure 4. Number of viable cells of Erwinia amylovora strain LMG 2024 after treatment with different concentrations of AMPs for flow cytometry (FC) assay. Vertical bars: mean value with standard deviation $(n=3)$; ${ }^{* * *}$ refer to the statistical significances for differences in each individual concentration of the analysis with $p<0.0001$. Different letters indicate statistical differences between treatments $(p<0.0001)$.

\section{Discussion}

AMPs have taken the spotlight, mainly in the last 15 years, as green bio-and ecofriendly compounds with potential to be used in agriculture to control phytopathogenic bacteria and fungi, complementing or replacing the existing agrochemicals. Nevertheless, some AMPs that have proven efficacy against a batch of plant pathogenic bacteria have not yet been tested in E. amylovora. Additionally, most of the studies with AMPs relied on one or very few strains of each pathogen, not providing a representative information of that population's behavior to the AMPs [33,44,46,55].

This study, besides the previously tested BP100, assessed for the first time the effect of five AMPs, using a wide and diverse number of wild and reference strains, thus providing a more representative information of the behavior of E. amylovora populations to the AMPs, with D4E1 being the only one previously tested against other phytopathogenic bacteria [52].

The antibiogram screened the effect of the six AMPs on 36 strains, disclosing which AMP were more efficient, and provided average values which could be considered representative of the bacteria population. This first screening showed that the AMPs 3.1, D4E1, and Dhvar-5 were less effective than BP100, RW-BP100, and CA-M. Regarding the AMPs to which E. amylovora was more susceptible, the results with the 36 field strains tested show that the effect of the peptides is virtually similar for both the field and reference strains, with $83.3,55.6$, and $66.7 \%$ of the strains displaying the same susceptibility for BP100, RW-BP100, and CA-M, respectively, for the lower concentration that created a halo.

Previous works described that D4E1 was highly efficient against P. syringae pv. tabaci and X. campestris pv. malvacearum, with MIC values of 2.25 and $1.25 \mu \mathrm{M}$ [52], while peptide 3.1 showed MIC values of $3.1 \mu \mathrm{M}$ against K. pneumoniae, but at the same time demonstrated a MIC value of $25 \mu \mathrm{M}$ against Pseudomonas aeruginosa [50]. Although Dhvar-5 has shown potential in inhibiting some Gram-positive bacteria [56], its mode of action, previously hypothesized to differ from that of the other five tested AMPs, did not present efficacy 
against E. amylovora. This propels the need for further bioactivity and molecular studies for the test peptides, to infer on the molecular basis for their distinctive efficiency against Gramnegative phytopathogenic bacteria. In fact, considering that different AMPs may disrupt or permeabilize the bacterial membranes and may undergo different conformational changes upon adsorption onto those membrane [57], thus influencing their mode of action, further studies with the active peptides should be made to investigate the molecular basis of their bioactivity against $E$. amylovora.

The differential susceptibility of E. amylovora against the test AMPs, as compared to those of other pathogens, can be explained by the different lipid composition of its cell membrane, which will therefore influence how the AMPs interact with it [58].

Evaluation of the antibacterial activity demonstrated that the peptides RW-BP100 and CA-M presented activities like that of the reference AMP BP100, which had been already tested on E. amylovora $[29,44,59]$. These studies showed BP100 MIC values between 2.5 and $7.5 \mu \mathrm{M}$ for E. amylovora, which is in line with our observations for the strains tested. Interestingly, MIC values for the three best AMPs herein tested are lower than those recently reported for other peptides [31].

The MIC values for CA-M were lower or similar to those previously obtained for the same peptide against other Gram-negative bacteria, e.g., Acinetobacter baumannii and E. coli, which disclosed MIC and MBC ranging from 4 to $64 \mu \mathrm{M}$ and 16 to $128 \mu \mathrm{M}$, respectively [60]. In the study of Oddo et al. [55], RW-BP100 displayed MIC values of $8 \mu \mathrm{M}$ against distinct strains of P. aeruginosa and K. pneumoniae, whilst a strain of E. coli showed MIC of $2 \mu \mathrm{M}$, which is respectively higher and lower than the values obtained in the present study $(5 \mu \mathrm{M})$.

Regarding the bactericidal versus bacteriostatic effects of these AMPs, data herein reported are in accordance with what had been reported in other studies on RW-BP100, which showed lower MBC values than BP100 against Gram-negative bacteria, namely, E. coli and P. aeruginosa [47]. Furthermore, MBC values for RW-BP100 match their MIC values, disclosing an effective bactericidal effect at $5 \mu \mathrm{M}$, whilst BP100 displays a bacteriostatic effect at the same concentration, being bactericidal only at concentrations from 8 to $20 \mu \mathrm{M}$. The fact that CA-M displayed similar values of MBC and MIC, as it happened with RW-BP100, show that CA-M also presents a bactericidal effect against E. amylovora, in line with what was previously reported for this peptide against other Gram-negative pathogens [61]. Bactericidal compounds cause bacterial cell death, which means that their inhibitory effects remain constant since the moment they are applied. On the other hand, bacteriostatic compounds merely inhibit normal bacterial growth, which means that their inhibition effects are exerted only when the bacteria are exposed to them; hence, bacteria can restore their growth capacity once optimal conditions are resumed [44].

To further assess possible variability of the effects of the AMPs in different strains, the $\mathrm{IC}_{50}$ was calculated. $\mathrm{IC}_{50}$ values are in accordance with the MIC values obtained for each strain and for each AMP. Thus, the peptide that induced lower $\mathrm{IC}_{50}$ for E. amylovora was RW-BP100 ( $30 \%$ less the MIC value), with CA-M presenting the higher $\mathrm{IC}_{50}$ values. Interestingly, both RW-BP100 and BP100 displayed significantly different group $\mathrm{IC}_{50}$ values when compared to CA-M. These distinct $\mathrm{IC}_{50}$ values may be due to slight differences in either conformation or bacterial killing kinetics among the peptides, which can be evaluated through the growth of the bacterium.

Regarding the sub-lethal doses of the three AMPs, it was possible to disclose that these peptides induce changes in bacterial growth at doses as low as $3.4 \mu \mathrm{M}$, especially for BP100, being those changes more pronounced at the concentration immediately below the MIC, causing a significantly delay in the growth lag phase and therefore also in the exponential phase of E. amylovora. These results are in alignment with the MIC values determined for the same strains. The stimulus that occurs in some strains at lower concentrations $(3.4 \mu \mathrm{M})$, which proved to be a non-lethal concentration, may be due to a stress that happens in the pathogen, as already reported for Listeria monocytogenes [62]. This serves as an indicator of the bactericidal effect of these AMPs, since above these values no growth was observed. Further 
studies must be applied to obtain further clarification about these factors. Although different methodologies can be used to evaluate $\mathrm{IC}_{50}$, our results are aligned with previous studies.

The results presented in this study further support what has been previously established for the AMPs activity in other pathogens, which may be due to the various modes of action that these peptides induce cell membrane disruption; this is related to their aa sequence, which can lead to different modes of membrane-destabilizing action (e.g., barrel stave-poration, toroidal poration, non-porating carpet model, charge-based phospholipid clustering, among others) $[63,64]$. These differences can also be attributed to factors not related to the AMPs, such as, the phospholipid composition and/or fluidity of the membrane, $\mathrm{pH}$, temperature and ionic stress [64], thus proving the necessity to widen the research of these biomolecules against a larger panel of bacteria.

Pathogen cell viability has been evaluated before resorting to FC, to infer bacterial membrane permeability [29,65-67]. In the present work, FC was used to test every AMP for their membrane-permeabilizing action on E. amylovora, showing that increasing concentrations of the peptides cause an increase in the fluorescence signal due to PI, i.e., a dose dependent response was obtained that correlates with the extent of bacterial membrane disruption. This is in accordance with what was previously described by O'Brien-Simpson [68], and further confirm that the bactericidal effects of these AMPs are principally associated with disruption of the pathogen cell membrane, which agrees with previous studies of these AMPs $[44,47,64,69]$.

Type strain LMG 2024 presented decreased cell viability in the presence of all BP100 concentrations tested, with the most pronounced results (decrease of $73.7 \%$ ) being achieved after a 120-min exposure to $8 \mu \mathrm{M}$. BP100 effects on E. amylovora may not be too severe, allowing for its cells to recover in optimal conditions, as it was shown in the UFC plate counting. These findings suggest that CA-M has the fastest action in decreasing the total cell viability, at low concentrations ( 5 and $8 \mu \mathrm{M}$ ), which was corroborated by plate counting, where no bacteria grew after $24 \mathrm{~h}$ of incubation. At the same time, CA-M induced the higher membrane permeability at both concentrations, with cell viability decreasing below $50 \%$ after $30 \mathrm{~min}$ of exposure, and after $60 \mathrm{~min}$ it was decreased below $15 \%$ for all tested concentrations. These results demonstrate a great potential for this peptide to control E. amylovora. Regarding the cell viability of the strains exposed to RW-BP100, once again the higher concentrations led to higher viability loss. This demonstrates a positive linear relation between AMPs concentration and reduction of cell viability.

Plate counting after $24 \mathrm{~h}$ showed that when E. amylovora was exposed to both RWBP100 and CA-M peptides, there was no cell recovery/division, which is line with the bactericidal effect previously determined. Plate counting for RW-BP100 showed no viable cells after $24 \mathrm{~h}$, and MIC and MBC values of $5 \mu \mathrm{M}$, being in line with the proposed mechanism of action for this AMP, i.e., bacterial cell membrane disruption [47].

Our results allow to infer that besides being dose-dependent, cell viability, and therefore, membrane disruption/permeabilization occurs along time starting from exposure to the tested AMPs, with a significant decrease after $60 \mathrm{~min}$ for CA-M, and $120 \mathrm{~min}$ for RW-BP100. This time-dependent membrane disruption is in accordance to what has been hypothesized for the mode of action of the AMPs, in which they accumulate over time on the outer membrane, gradually promoting increasing disturbance in the lipid ordering, until disruption occurs [33]. Furthermore, this confers these AMPs a fast activity against the target pathogen. Both CA-M and RW-BP100 presented improved bioactivity as compared to BP100 at the same concentrations, which could propel them as improved biomolecular compounds to control this disease. Moreover, CA-M and RW-BP100 could be used in synergy with each other, or with BP100, in order to increase antibacterial potency, as several recent studies have highlighted the benefits of synergic interactions with AMPs [29,70-72]. Furthermore, these results shows that both RW-BP100 and CA-M, as also BP100 possess structures that allows them to successfully interact with the LPS of E. amylovora, which leads to membrane permeation, as it has been proved before as a critical aspect for AMPs optimal efficiency [43]. 
Overall, when comparing BP100 with both CA-M and RW-BP100, the latter showed better efficiency, with lower MIC, MBC, $\mathrm{IC}_{50}, \mathrm{FC}$, and UFC plate counting values. These observations, along with low hemolytic activity previously reported for CA-M [44,73,74], advances these peptides as novel suitable candidates to be applied in agriculture control measures against bacterial diseases like fire blight.

\section{Conclusions}

This work had the objective of testing for the first time five AMPs against a diverse collection of E. amylovora, and compare their efficiency with that of BP100 previously described as effective against the pathogen. Our findings suggest that RW-BP100 and CA-M peptides are highly active against E. amylovora, making them good candidates to control this pathogen, since in the antimicrobial, cell viability and cell recovery assays they demonstrated better results than BP100. Data also suggest a population reproducibility regarding E. amylovora. Nevertheless, future studies in planta, and in vitro must be applied in order to further disclose the function and efficacy of these AMPs, and how they affect the metabolism of the pathogen and interact with the bacteria membrane. Additionally, synergic studies with the combination of the most effective AMPs found here would represent a new step to the use of AMPs in agriculture.

Supplementary Materials: The following are available online at https://www.mdpi.com/article/ 10.3390/biom11040554/s1, Figure S1: Mass spectrum (ESI-IT, positive mode) of peptide BP100 $(\mathrm{MW}=1419.9 \mathrm{Da})$, highlighting the quasi-molecular ion $\left([\mathrm{P}+\mathrm{H}]^{+}\right)$, its sodium adduct $\left([\mathrm{P}+\mathrm{Na}]^{+}\right.$, base peak), the di-protonated $\left([\mathrm{P}+2 \mathrm{H}]^{2+}\right)$ ion and its sodium adduct $\left([\mathrm{P}+2 \mathrm{Na}]^{2+}\right)$, and the tri-protonated $\left([\mathrm{P}+3 \mathrm{H}]^{3+}\right)$ and tetra-protonated $\left([\mathrm{P}+4 \mathrm{H}]^{4+}\right)$ ions of the target peptide (P), Figure S2: RP-HPLC chromatogram for peptide BP100, after purification; gradient elution from 1 to $100 \% \mathrm{ACN}$ in $0.05 \%$ aqueous TFA at $1 \mathrm{~mL} / \mathrm{min}$ flow rate, for $30 \mathrm{~min}$, on a C-18 column $(150 \times 4.6 \mathrm{~mm}$ ID and $5 \mu \mathrm{m}$ pore size); detection at $220 \mathrm{~nm}$, Figure S3: Mass spectrum (ESI-IT, positive mode) of peptide RW-BP100 $(\mathrm{MW}=1583.0 \mathrm{Da})$, highlighting the quasi-molecular ion $\left([\mathrm{P}+\mathrm{H}]^{+}\right)$, the di-protonated $\left([\mathrm{P}+2 \mathrm{H}]^{2+}\right.$, base peak) ion and respective sodium adduct $\left([\mathrm{P}+2 \mathrm{Na}]^{2+}\right)$, the tri-protonated ion $\left([\mathrm{P}+3 \mathrm{H}]^{3+}\right)$ and its sodium and dipotassium adduct $\left([\mathrm{P}+\mathrm{Na}+2 \mathrm{~K}]^{3+}\right)$, and the tetra-protonated $\left([\mathrm{P}+4 \mathrm{H}]^{4+}\right)$ ion of the target peptide (P), Figure S4: RP-HPLC chromatogram for peptide RW-BP100, after purification; gradient elution from 1 to $100 \% \mathrm{ACN}$ in $0.05 \%$ aqueous TFA at $1 \mathrm{~mL} / \mathrm{min}$ flow rate, for $30 \mathrm{~min}$, on a C- 18 column $(150 \times 4.6 \mathrm{~mm}$ ID and $5 \mu \mathrm{m}$ pore size); detection at $220 \mathrm{~nm}$, Figure S5: Mass spectrum (ESI-IT, positive mode) of peptide CA-M $(\mathrm{MW}=1769.2 \mathrm{Da})$, showing the quasi-molecular ion $\left([\mathrm{P}+\mathrm{H}]^{+}\right)$, the di-protonated $\left([\mathrm{P}+2 \mathrm{H}]^{2+}\right.$, base peak), the tri-protonated $\left([\mathrm{P}+3 \mathrm{H}]^{3+}\right)$, and the tetra-protonated $\left([\mathrm{P}+4 \mathrm{H}]^{4+}\right)$ ions of the target peptide $(\mathrm{P})$, Figure S6: RP-HPLC chromatogram for peptide CA-M after purification; gradient elution from 1 to $100 \% \mathrm{ACN}$ in $0.05 \%$ aqueous TFA at $1 \mathrm{~mL} / \mathrm{min}$ flow rate, for $30 \mathrm{~min}$, on a C-18 column $(150 \times 4.6 \mathrm{~mm}$ ID and $5 \mu \mathrm{m}$ pore size); detection at $220 \mathrm{~nm}$, Figure S7: Mass spectrum (ESI-IT, positive mode) of peptide D4E1 (MW = 2079.4 Da), highlighting the di-protonated $\left([\mathrm{P}+2 \mathrm{H}]^{2+}\right.$, base peak), tri-protonated $\left([\mathrm{P}+3 \mathrm{H}]^{3+}\right)$ and tetra-protonated $\left([\mathrm{P}+4 \mathrm{H}]^{4+}\right)$ ions of the target peptide (P), Figure S8: RP-HPLC chromatogram for peptide D4E1, after purification; gradient elution from 1 to $100 \% \mathrm{ACN}$ in $0.05 \%$ aqueous TFA at $1 \mathrm{~mL} / \mathrm{min}$ flow rate, for $30 \mathrm{~min}$, on a C-18 column $(150 \times 4.6 \mathrm{~mm}$ ID and $5 \mu \mathrm{m}$ pore size); detection at $220 \mathrm{~nm}$, Figure S9: Mass spectrum (ESI-IT, positive mode) of peptide $3.1(\mathrm{MW}=1393.9 \mathrm{Da})$, showing the quasi-molecular $\left([\mathrm{P}+\mathrm{H}]^{+}\right.$, base peak), di-protonated $\left([\mathrm{P}+2 \mathrm{H}]^{2+}\right)$, tri-protonated $\left([\mathrm{P}+3 \mathrm{H}]^{3+}\right)$ and tetra-protonated $\left([\mathrm{P}+4 \mathrm{H}]^{4+}\right)$ ions of the target peptide (P), Figure S10: RP-HPLC chromatogram for peptide 3.1, after purification; gradient elution from 1 to $100 \% \mathrm{ACN}$ in $0.05 \%$ aqueous TFA at $1 \mathrm{~mL} / \mathrm{min}$ flow rate, for $30 \mathrm{~min}$, on a C-18 column $(150 \times 4.6 \mathrm{~mm}$ ID and $5 \mu \mathrm{m}$ pore size $)$; detection at $220 \mathrm{~nm}$, Figure S11: Mass spectrum (ESI-IT, positive mode) of peptide Dhvar-5 (MW = 1845.3 Da), highlighting the di-protonated ion $\left([\mathrm{P}+2 \mathrm{H}]^{2+}\right.$, base peak), the tri-protonated ion $\left([\mathrm{P}+3 \mathrm{H}]^{3+}\right)$, the tetra-protonated ion $\left([\mathrm{P}+4 \mathrm{H}]^{4+}\right)$ and its sodium adduct $\left([\mathrm{P}+4 \mathrm{Na}]^{4+}\right)$, and the penta-sodium adduct $\left([\mathrm{P}+5 \mathrm{Na}]^{5+}\right)$ of the target peptide (P), Figure S12: RP-HPLC chromatogram for peptide Dhvar-5, after purification; gradient elution from 1 to $100 \% \mathrm{ACN}$ in $0.05 \%$ aqueous TFA at $1 \mathrm{~mL} / \mathrm{min}$ flow rate, for $30 \mathrm{~min}$, on a C-18 column $(150 \times 4.6 \mathrm{~mm}$ ID and $5 \mu \mathrm{m}$ pore size); detection at $220 \mathrm{~nm}$, Figure S13: Growth curves of eight E. amylovora strains exposed to increasing concentrations of BP100 $(0,1.6,3.4$, and $5 \mu \mathrm{M})$. Vertical bars: mean value with standard deviation $(n=3)$, Figure S14: Growth curves of eight E. amylovora strains 
exposed to increasing concentrations of RW-BP100 $(0,1.6$, and $3.4 \mu \mathrm{M})$. Vertical bars: mean value with standard deviation $(n=3)$, Figure S15: Growth curves of eight E. amylovora strains exposed to increasing concentrations of CA-M $(0,1.6,3.4$, and $5 \mu \mathrm{M})$. Vertical bars: mean value with standard deviation $(n=3)$, Table S1: AMPs antibiogram susceptibility. (+): inhibition occurred; (-): inhibition did not occur; C+: Type strain LMG 2024.

Author Contributions: Conceptualization, R.J.M., F.T., and C.S.; Data curation, R.J.M., F.T., and C.S.; Formal analysis, R.J.M., J.P.L., F.T., and C.S.; Funding acquisition, C.S.; Investigation, R.J.M., L.R., J.P.L., N.T., C.T., and P.G.; Methodology, R.J.M., L.R., J.P.L., N.T., C.T., P.G., F.T., and C.S.; Resources, R.J.M., N.T., C.T., P.G., F.T., and C.S.; Supervision, F.T. and C.S.; Writing-original draft, R.J.M.; Writing-review \& editing, R.J.M., L.R., J.P.L., N.T., C.T., P.G., F.T., and C.S. All authors have read and agreed to the published version of the manuscript.

Funding: Rafael J. Mendes and C. Santos were financed by Fundação para a Ciência e a Tecnologia (FCT) with the grant SFRH/BD/133519/2017, and by FEDER-Fundo Europeu de Desenvolvimento Regional funds through the COMPETE 2020-Operacional Programme for Competitiveness and Internationalization (POCI) within the scope of projects UIDB/50006/2020 (LAQV-REQUIMTE), respectively, and PTDC/BAA-AGR/31798/2017 (POCI-01-0145-FEDER-31798).

Data Availability Statement: Following the MDPI Research Data Policies, data from this paper will be available under request.

Acknowledgments: The authors would like to thank Conceição Amaro for the culture maintenance of the bacterial strains at IPCB.

Conflicts of Interest: The authors declare no conflict of interest.

\section{References}

1. Vanneste, J.L. What is Fire Blight? Who is Erwinia amylovora? How to Control it? In Fire Blight, The Disease and Its Causative Agent, Erwinia Amylovora; Vanneste, J.L., Ed.; CABI: New York, NY, USA, 2000.

2. Sundin, G.W. Infectious Diseases. In Compendium of Apple and Pear Diseases and Pests; Sutton, T.B., Aldwinckle, H.S., Agnello, A.M., Walgenbach, J.F., Eds.; American Phytopathological Society: St. Paul, MN, USA, 2014.

3. Norelli, J.L.; Jones, A.L.; Aldwinckle, H.S. Fire blight management in the twenty first century using new technologies. Plant Dis. 2003, 87, 756-765. [CrossRef] [PubMed]

4. Mansfield, J.; Genin, S.; Magori, S.; Citovsky, V.; Sriariyanum, M.; Ronald, P.; Dow, M.; Verdier, V.; Beer, S.V.; Machado, M.A.; et al. Top 10 plant pathogenic bacteria in molecular plant pathology. Mol. Plant Pathol. 2012, 13, 614-629. [CrossRef] [PubMed]

5. EPPO. EPPO A1 and A2 lists of pests recommended for regulation as quarantine pests. PM 1/2(28) English. EPPO Stand. 2019, 1-18.

6. Halupecki, E.; Bazzi, C.; Jock, S.; Geider, K.; Dermić, D.; Cvjetković, B. Characterization of Erwinia amylovora strains from Croatia. Eur. J. Plant Pathol. 2006, 114, 435-440. [CrossRef]

7. McGhee, G.; Sundin, G.W. Erwinia amylovora CRISPR elements provide new tools for evaluating strain diversity and for microbial source tracking. PLoS ONE 2012, 7, e41706. [CrossRef] [PubMed]

8. Végh, A.; Némethy, Z.; Hajagos, L.; Palkovics, L. First report of Erwinia amylovora causing fire blight on plum (Prunus domestica L.) in Hungary. Plant Dis. 2012, 96, 759. [CrossRef]

9. Rhouma, A.; Helali, F.; Chettaoui, M.; Hajlaoui, M.R. First report of fire blight caused by Erwinia amylovora on pear in Tunisia. Plant Dis. 2014, 98, 158. [CrossRef]

10. Llorente, I.; Vilardell, P.; Isern, M.; Montesinos, E.; Moragrega, C. Fire blight risk assessment in girona region (Catalonia): Comparison of maryblyt and cougarblight models. J. Plant Pathol. 2017, 99, 75-80.

11. Doolotkeldieva, T.; Bobushova, S.; Schuster, C.; Konurbaeva, M.; Leclerque, A. Isolation and genetic characterization of Erwinia amylovora bacteria from Kyrgyzstan. Eur. J. Plant Pathol. 2019, 155, 677-686. [CrossRef]

12. Popović, T.; Jelušić, A.; Živković, L.; Živković, N.; Iličić, R.; Stanisavljević, R.; Stanković, S. Identification, genetic characterization and virulence of Serbian Erwinia amylovora isolates. Eur. J. Plant Pathol. 2020, 157, 857-872. [CrossRef]

13. Song, J.Y.; Yun, Y.H.; Kim, G.; Kim, S.H.; Lee, S.J.; Kim, J.F. Genome analysis of Erwinia amylovora strains responsible for a fire blight outbreak in Korea. Plant Dis. 2020. [CrossRef] [PubMed]

14. Mendes, R.J.; Luz, J.P.; Santos, C.; Tavares, F. CRISPR genotyping as complementary tool for epidemiological surveillance of Erwinia amylowora outbreaks. PLoS ONE 2021. [CrossRef]

15. Joos, M.; Hummrich, A.; Voegele, R.T. The effect of phytosanitary measures against fire blight in infected apple orchards. Acta Hortic. 2014, 1056, 77-80. [CrossRef]

16. Shtienberg, D.; Manulis-Sasson, S.; Zilberstaine, M.; Oppenheim, D.; Shwartz, H. The Incessant Battle against Fire Blight in Pears: 30 Years of Challenges and Successes in Managing the Disease in Israel. Plant Dis. 2015, 99, 1048-1058. [CrossRef] 
17. Mendes, R.J.; Mariz-Ponte, N.; Correia, C.V.; Dias, M.C.; Sousa, M.L.; Tavares, F.; Santos, C. Fire blight management: Physiological assessment of cultural control by pruning in pear orchards. Agriculture 2020, 66, 128-136.

18. European Commission. Commission Regulation (EC) No 473/2002. Off. J. Eur. Communities 2002.

19. Lamichhane, J.R.; Osdaghi, E.; Behlau, F.; Köhl, J.; Jones, J.B.; Aubertot, J. Thirteen decades of antimicrobial copper compounds applied in agriculture. A review. Agron. Sustain. Dev. 2018, 38, 1-18. [CrossRef]

20. Sundin, G.W.; Castiblanco, L.F.; Yuan, X.; Zeng, Q.; Yang, C.H. Bacterial disease management: Challenges, experience, innovation and future prospects: Challenges in bacterial molecular plant pathology. Mol. Plant Pathol. 2016, 17, 1506-1518. [CrossRef]

21. Sundin, G.W.; Wang, N. Antibiotic Resistance in Plant-Pathogenic Bacteria. Annu. Rev. Phytopathol. 2018, 56, 161-180. [CrossRef]

22. Buttimer, C.; McAuliffe, O.; Ross, R.P.; Hill, C.; O'Mahony, J.; Coffey, A. Bacteriophages and bacterial plant diseases. Front. Microbiol. 2017, 8, 1-15. [CrossRef] [PubMed]

23. Dagher, F.; Olishevska, S.; Philion, V.; Zheng, J.; Déziel, E. Development of a novel biological control agent targeting the phytopathogen Erwinia amylovora. Heliyon 2020, 6, e05222. [CrossRef] [PubMed]

24. Mikiciński, A.; Pulawsja, J.; Molzhigitova, A.; Sobiczewski, P. Bacterial species recognized for the first time for its biocontrol activity against fire blight (Erwinia amylovora). Eur. J. Plant Pathol. 2020, 156, 257-272. [CrossRef]

25. Akhlaghi, M.; Tarighi, S.; Taheri, P. Effects of plant essential oils on growth and virulence factors of Erwinia amylovora. J. Plant Pathol. 2019, 102, 409-419. [CrossRef]

26. Costa, T.; Luz, J.P.; Amaro, C.; Dias, S.; Ferreira, F.M.; Castro, P.; Galhano, C. Medicinal and aromatic plants (MAP) as potential antibiotics to control fire blight. In Proceedings of the International Congress on Organizational Management, Energy Efficiency and Occupational Health and Safety in Agrifood Industry (+AGRO 2018); CEi: Castelo Branco, Portugal, 2019.

27. Montesinos, E. Antimicrobial peptides and plant disease control. FEMS Microbiol. Lett. 2007, 270, 1-11. [CrossRef]

28. Montesinos, E.; Badosa, E.; Cabrefiga, J.; Planas, M.; Feliu, L.; Bardají, E. Antimicrobial peptides for plant disease control. From discovery to application. In Small Wonders: Peptides for Disease Control; Rajasekaran, K., Cary, J., Jaynes, J., Montesinos, E., Eds.; Oxford University Press: Washington, DC, USA, 2012.

29. Cabrefiga, J.; Montesinos, E. Lysozyme enhances the bactericidal effect of BP100 peptide against Erwinia amylovora, the causal agent of fire blight of rosaceous plants. BMC Microbiol. 2017, 17, 1-10. [CrossRef] [PubMed]

30. Ilyas, H.; Datta, A.; Bhunia, A. An approach towards structure based antimicrobial peptide design for use in development of transgenic plants: A strategy for plant disease management. Curr. Med. Chem. 2017, 24, 1350-1364. [CrossRef]

31. Glossop, H.D.; De Zoysa, G.H.; Pilkington, L.I.; Barker, D.; Sarojini, V. Fluorinated O-phenylserine residues enhance the broad-spectrum antimicrobial activity of ultrashort cationic lipopeptides. J. Fluor. Chem. 2021, 241, 109685. [CrossRef]

32. Ageitos, J.M.; Sánchez-Pérez, A.; Calo-Mata, P.; Villa, T.G. Antimicrobial peptides (AMPs): Ancient compounds that represent novel weapons in the fight against bacteria. Biochem. Pharmacol. 2017, 133, 117-138. [CrossRef] [PubMed]

33. Li, S.; Wang, Y.; Xue, Z.; Jia, Y.; Li, R.; He, C.; Chen, H. The structure-mechanism relationship and mode of actions of antimicrobial peptides: A review. Trends Food Sci. Tech. 2021, 109, 103-115. [CrossRef]

34. Brogden, K.A. Antimicrobial peptides: Pore formers or metabolic inhibitors in bacteria? Nat. Rev. Microbiol. 2005, 3, 238-250. [CrossRef] [PubMed]

35. Matsuzaki, K. Control of cell selectivity of antimicrobial peptides. Biochim. Biophys. Acta 2009, 1788, 1687-1692. [CrossRef] [PubMed]

36. Arouri, A.; Dathe, M.; Blume, A. Peptide induced demixing in PG/PE lipid mixtures: A mechanism for the specificity of antimicrobial peptides towards bacterial membranes? Biochim. Biophys. Acta Biomembr. 2009, 1788, 650-659. [CrossRef] [PubMed]

37. Monroc, S.; Badosa, E.; Besalú, E.; Planas, M.; Bardají, E.; Montesinos, E.; Feliu, L. Improvement of cyclic decapeptides against plant pathogenic bacteria using a combinatorial chemistry approach. Peptides 2006, 27, 2575-2584. [CrossRef] [PubMed]

38. Ali, G.S.; Reddy, A.S. Inhibition of fungal and bacterial plant pathogens by synthetic peptides: In vitro growth inhibition, interaction between peptides and inhibition of disease progression. Mol. Plant Microbe. Interact 2000, 13, 847-859. [CrossRef] [PubMed]

39. Dash, R.; Bhattacharjya, S. Thanatin: An emerging host defense antimicrobial peptide with multiple modes of action. Int. J. Mol. Sci. 2021, 22, 1522. [CrossRef]

40. Baró, A.; Badosa, E.; Montesinos, L.; Feliu, L.; Planas, M.; Montesinos, E.; Bonaterra, A. Screening and identification of BP100 peptide conjugates active against Xylella fastidiosa using a viability-qPCR method. BMC Microbiol. 2020, 20, 229. [CrossRef]

41. Datta, A.; Ghosh, A.; Airoldi, C.; Sperandeo, P.; Mroue, K.H.; Jiménez-Barbero, J.; Kundu, P.; Ramamoorthy, A.; Bhunia, A. Antimicrobial Peptides: Insights into Membrane Permeabilization, Lipopolysaccharide Fragmentation and Application in Plant Disease Control. Sci. Rep. 2015, 5, 11951. [CrossRef]

42. Mariz-Ponte, N.; Regalado, L.; Gimranov, E.; Tassi, N.; Moura, L.; Gomes, P.; Tavares, F.; Santos, C.; Teixeira, C. A Synergic Potential of Antimicrobial Peptides against Pseudomonas syringae pv. actinidiae. Molecules 2021, 26, 1461. [CrossRef]

43. Bhattacharjya, S. NMR structures and interactions of antimicrobial peptides with Lipopolysaccharide: Connecting structures to functions. Curr. Top. Med. Chem. 2016, 16, 4-15. [CrossRef]

44. Badosa, E.; Ferre, R.; Planas, M.; Feliu, L.; Besaluâ, E.; Cabrefiga, J.; Bardají, E.; Montesinos, E. A library of linear undecapeptides with bactericidal activity against phytopathogenic bacteria. Peptides 2007, 28, 2276-2285. [CrossRef]

45. Badosa, E.; Ferre, R.; Franceâs, J.; Bardajõâ, E.; Feliu, L.; Planas, M.; Montesinos, E. Sporicidal activity of synthetic antifungal undecapeptides and control of Penicillium rot of apples. Appl. Environ. Microbiol. 2009, 75, 5563-5569. [CrossRef] 
46. Güell, I.; Cabrefiga, J.; Badosa, E.; Ferre, R.; Talleda, M.; Bardají, E.; Planas, M.; Feliu, L.; Montesinos, E. Improvement of the efficacy of linear undecapeptides against plant-pathogenic bacteria by incorporation of D-amino acids. App Environ. Microbiol. 2011, 77, 2667-2675. [CrossRef] [PubMed]

47. Torcato, I.M.; Huang, Y.H.; Franquelim, H.G.; Gaspar, D.; Craik, D.J.; Castanho, M.A.R.B.; Troeira, H.S. Design and characterization of novel antimicrobial peptides, R-BP100 and RW-BP100, with activity against Gram-negative and Gram-positive bacteria. BBA Biomembr. 2013, 1828, 944-955. [CrossRef] [PubMed]

48. Saugar, J.M.; Rodríguez-Hernández, M.J.; Torre, B.G.; Pachón-Ibañez, M.E.; Fernández-Reyes, M.; Andreu, D.; Pachón, J.; Rivas, L. Activity of cecropin A-melittin hybrid peptides against colistin-resistant clinical strains of Acinetobacter baumannii: Molecular basis for the differential mechanisms of action. Antimicrob. Agents Chemother. 2006, 50, 1251-1256. [CrossRef] [PubMed]

49. López-Rojas, R.; Docobo-Pérez, F.; Pachón-Ibáñez, M.E.; De La Torre, B.G.; Fernández-Reyes, M.; March, C.; Bengoechea, J.A.; Andreu, D.; Rivas, L.; Pachón, J. Efficacy of cecropin A-melittin peptides on a sepsis model of infection by pan-resistant Acinetobacter baumannii. Eur. J. Clin. Microbiol. 2011, 20, 1391-1398. [CrossRef] [PubMed]

50. Kang, S.J.; Won, H.S.; Choi, W.S.; Lee, B.J. De novo generation of antimicrobial LK peptides with a single tryptophan at the critical amphipathic interface. J. Pept. Sci. 2009, 15, 583-588. [CrossRef] [PubMed]

51. Gomes, A.S.M.; Bessa, L.J.; Fernandes, I.; Ferraz, R.; Mateus, N.; Gameiro, P.; Teixeira, C.; Gomes, P. Turning a collagenesis-inducing peptide into a potent antibacterial and antibiofilm agent against multidrug-resistant Gram-negative bacteria. Front. Microb. 2019, 10, 1915. [CrossRef] [PubMed]

52. Rajasekaran, K.; Stromberg, K.D.; Cary, J.W.; Cleveland, T.E. Broad-Spectrum Antimicrobial Activity in vitro of the Synthetic Peptide D4E1. J. Agric. Food Chem. 2001, 49, 2799-2803. [CrossRef]

53. Faber, C.; Hoogendoorn, R.J.W.; Stallmann, H.P.; Lyaruu, D.M.; van Nieuw Amerongen, A.; Wuisman, P.I.J.M. In vitro comparison of Dhvar-5 and gentamicin in an MRSA osteomyelitis prevention model. J. Antimicrob. Chem. 2004, 54, 1078-1084. [CrossRef]

54. Behrendt, R.; White, P.; Offer, J. Advances in Fmoc solid-phase peptide synthesis. J. Pept. Sci. 2016, 22, 4-27. [CrossRef]

55. Oddo, A.; Thomsen, T.T.; Kjelstrup, S.; Gorey, C.; Franzyk, H.; Frimodt-Møller, N.; Løbner-Olesen, A.; Hansen, P.R. An amphipathic undecapeptide with all D-amino acids shows promising activity against colistin-resistant strains of Acinetobacter baumannii and a dual mode of action. Antimicrob. Agents Chemother. 2016, 60, 592-599. [CrossRef]

56. Costa, F.M.T.A.; Maia, S.R.; Gomes, P.A.C.; Martins, M.C.L. Dhvar5 antimicrobial peptide (AMP) chemoselective covalent immobilization results on higher antiadherence effect than simple physical adsorption. Biomaterials 2015, 52, 531-538. [CrossRef]

57. Li, J.; Koh, J.J.; Liu, S.; Lakshminarayanan, R.; Verma, C.S.; Beuerman, R.W. Membrane active antimicrobial peptides: Translating mechanistic insights to design. Front. Neurosci. Switz. 2017, 11, 73. [CrossRef] [PubMed]

58. Huang, H.W. Action of antimicrobial peptides: Two-state model. Biochemistry 2000, 39, 8347-8352. [CrossRef]

59. Badosa, E.; Montesinos, L.; Montesinos, E.; Feliu, L.; Planas, M.; Bardají, E. Prospects and limitations of synthetic antimicrobial peptides for fire blight control. Acta Hortic. 2014, 1056, 111-116. [CrossRef]

60. Moghaddam, M.M.; Abolhassani, F.; Babavalian, H.; Mirnejad, R.; Barjini, K.A.; Amani, J. Comparison of in vitro antibacterial activities of two cationic peptides CM15 and CM11 against five pathogenic bacteria: Pseudomonas aeruginosa, Staphylococcus aureus, Vibrio cholerae, Acinetobacter baumannii, and Escherichia coli. Probiotics Antimicrob. 2012, 4, 133-139. [CrossRef] [PubMed]

61. Agbale, C.M.; Sarfo, J.K.; Galyuon, I.K.; Juliano, S.A.; Silva, G.G.O.; Buccini, D.F.; Cardoso, M.H.; Torres, M.D.T.; Angeles-Boza, A.M.; De La Fuente-Nunez, C.; et al. Antimicrobial and Antibiofilm Activities of Helical Antimicrobial Peptide Sequences Incorporating Metal-Binding Motifs. Biochemistry 2019, 58, 3802-3812. [CrossRef]

62. Bizani, D.; Morrissy, J.A.C.; Dominguez, A.P.M.; Brandelli, A. Inhibition of Listeria monocytogenes in dairy products using the bacteriocin-like peptide cerein 8A. Int. J. Food Microbiol. 2008, 121, 229-233. [CrossRef]

63. Mejía-Argueta, E.L.; Santillán-Benítez, J.G.; Ortiz-Reynos, M. Antimicrobial peptides, an alternative to combat bacterial resistance. Acta Biol. Colomb. 2020, 25, 294-302. [CrossRef]

64. Hammond, K.; Hoogenboom, B.W.; Ryadnov, M.G. Membrane disrupting peptides: Mechanistic elucidation of antimicrobial activity. Amino Acids Pept. Prot. 2021, 43, 115-139.

65. Chitarra, L.G.; Breeuwer, P.; Abee, T.; Bulk, R.W. The use of fluorescent probes to assess viability of the plant pathogenic bacterium Clavibacter michiganensis subsp. michiganensis by flow cytometry. Fitopatol. Bras. 2006, 31, 349-356. [CrossRef]

66. Ambriz-Avina, V.; Contreras-Garduno, J.A.; Pedraza-Reyes, M. Applications of Flow Cytometry to Characterize Bacterial Physiological Responses. BioMed. Res. Int. 2014, 2014, 1-14. [CrossRef]

67. Shapiro, H.M. Microbial Cytometry: What It Was, Is, and May Be. In Flow Cytometry in Microbiology: Technology and Applications; Martin, G., Ed.; Caister Academic Press: Norfolk, UK, 2016.

68. O'Brien-Simpson, N.M.; Pantarat, N.; Attard, T.J.; Walsh, K.A.; Reynolds, E.C. A rapid and quantitative flow cytometry method for the analysis of membrane disruptive antimicrobial activity. PLoS ONE 2016, 11, e0151694. [CrossRef]

69. Rakowska, P.D.; Jiang, H.; Ray, S.; Pyne, A.; Lamarre, B.; Carr, M.; Judge, P.J.; Ravi, J.; Gerling, U.I.M.; Koksch, B.; et al. Nanoscale imaging reveals laterally expanding antimicrobial pores in lipid bilayers. Proc. Natl. Acad. Sci. USA 2013, 110, 8918-8923. [CrossRef] [PubMed]

70. Hanson, M.A.; Dostálová, A.; Ceroni, C.; Poidevin, M.; Kondo, S.; Lemaitre, B. Synergy and remarkable specificity of antimicrobial peptides in vivo using a systematic knockout approach. eLife 2019, 8, e44341. [CrossRef] 
71. Zharkova, M.S.; Orlov, D.S.; Golubeva, O.Y.; Chakchir, O.B.; Eliseev, I.E.; Grinchuk, T.M.; Shamova, O.V. Application of antimicrobial peptides of the innate immune system in combination with conventional antibiotics-a novel way to combat antibiotic resistance? Front. Cell Infect. Microbiol. 2019, 9, 128. [CrossRef] [PubMed]

72. Lazzaro, B.P.; Zasloff, M.; Rolff, J. Antimicrobial peptides: Application informed by evolution. Science 2020, 368 , eaau5480. [CrossRef]

73. Wade, D.; Andreu, D.; Mitchell, S.A.; Silveira, A.M.; Boman, A.; Boman, H.G.; Merrifield, R.B. Antibacterial peptides designed as analogs or hybrids of cecropins and melittin. Int. J. Pept. Protein. Res. 1992, 40, 429-436. [CrossRef] [PubMed]

74. Moore, A.J.; Beazley, W.D.; Bibby, M.C.; Devine, D.A. Antimicrobial activity of cecropins. J. Antimicrob. Chemother. 1996, 37, 1077-1089. [CrossRef] [PubMed] 